\title{
El género y la mascarada en la fotografía de María Santibáñez
}

\author{
[ Gender and masquerade in María Santibáñez' photographs
}

Deborah Dorotinsky Alperstein ${ }^{\mathrm{I}}$

\begin{abstract}
RESUMO - Este artigo propõe que nas fotografias de María Santibáñez, entre I920-I930, foram reproduzidos imaginários e experiências do corpo feminino capaz de atuar, que haviam sido apagados nas reconstruções historiográficas enraizadas na concepção da cultura mexicana como dicotomia entre a tradição e a modernidade. Através de temas estilísticos (greco-latino, oriental e espanhol), essas representações femininas criaram um espaço imaginativo para construir modelos de mulheres de classe média com uma vida interior "intensa". Como fotógrafa de estúdio, María Santibáñez invocou com essa iconografia uma tradição estetizante que elevou seu trabalho de fotografia comercial ao nível de criação artística e ao mesmo tempo afirmou uma experiência cultural sobre o que tinha bom gosto, era delicado, e tinha "classe". PALAVRAS-CHAVE - Fotografia; pictorialismo;
\end{abstract}

María Santibáñez; moças modernas; México. - ABSTRACT - This article proposes that in María Santibáñez' photographs between I920I930, visual imaginaries and experiences of the feminine body's agency were available to women, that have been made invisible by a deeply rooted historiographic dichotomy of Mexican culture torn between tradition and modernity. Through Greco-Roman, Oriental and Spanish themes, these feminine representations created an imaginative space to construct models for middle class women with an "intense" inner life. As a studio photographer, María Santibáñez invoked with this iconography an estheticizing tradition that elevated her commercial studio work to the level of artistic creation while at the same time asserted a cultural experience about what had good taste, was delicate and had "class". . KEYWORDS - Photography; pictorialism; María Santibáñez; modern girls; Mexico.

Recebido em 29 de março de 2018

Aprovado em Iํ. de novembro de 2018

DOROTINSKY ALPERSTEIN, Deborah. El género y la mascarada en la fotografía de María Santibáñez. Revista do Instituto de Estudos Brasileiros, Brasil, n. 7I, p. I32-I57, dez. 2018.

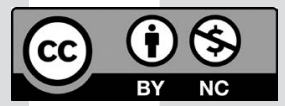

DOI: http://dx.doi.org/Io.II606/issn.23I6-90IX.voi7IpI32-I57

I Universidade Nacional Autônoma do México (UNAM, Cidade do México, MX, México). 


\section{SiluetaS DE la VIDA SOCIAL}

En enero y febrero de I92I aparecieron en la sección de retratos femeninos denominada "Siluetas Aristocráticas" en la revista mexicana El Universal Ilustrado, dos fotografías tomadas por María Santibáñez. En la primera (Figura I) la señorita María Teresa Viesca, vestida en un elaborado traje de encajes y listones, peluca blanca, canasta en mano y profusión de rosetas en el frente del vestido, posa sentada sobre una banca con el cuerpo de frente y el rostro inclinado modestamente. Su vestido y el medallón que enmarca la fotografía sugieren otros tiempos pasados, quizás pretenden evocar la gracia femenina dieciochesca. Del ruedo de su vestido resaltan los delicados zapatitos de raso que cubren sus pequeños pies. 


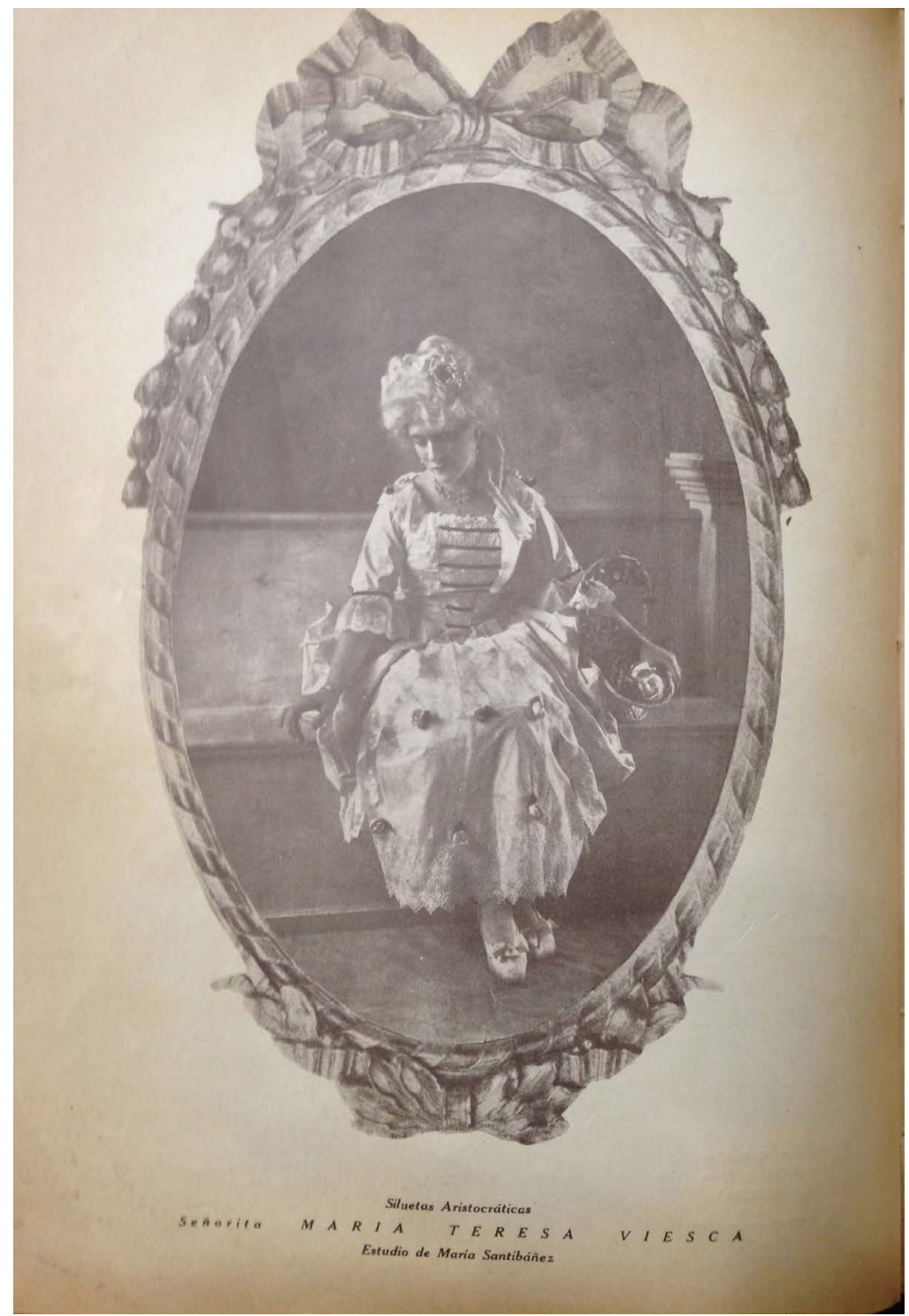

Figura I - María Santibáñez, “Señorita María Teresa Viesca”, Sección

“Siluetas Aristocráticas”, El Universal Ilustrado, 20 de enero I92I, n. I94, p. s/n. Hemeroteca de la Biblioteca Lerdo, Secretaría de Hacienda y Crédito Público

En la otra fotografía (Figura 2), un retrato de busto, la señorita Isabel Corona nos mira a los ojos en un perfil tres cuartos con la melena corta cubierta por un coqueto sombrero con velo. Cuerpo y rostro giran en direcciones contrarias encuadrados por un complejo marco florar. Estas fotografías formaron parte de una sección de la revista sobre bellezas femeninas nacionales en la que se mostraban, sobre todo, mujeres de la clase media y media alta mexicanas, así 
como estrellas de cine y teatro de revista ${ }^{2}$. En la negociación de la pose con la modelo, Santibáñez pretendió dar a cada una un toque personal que resaltara en el retrato su individualidad y cierta vida interior.

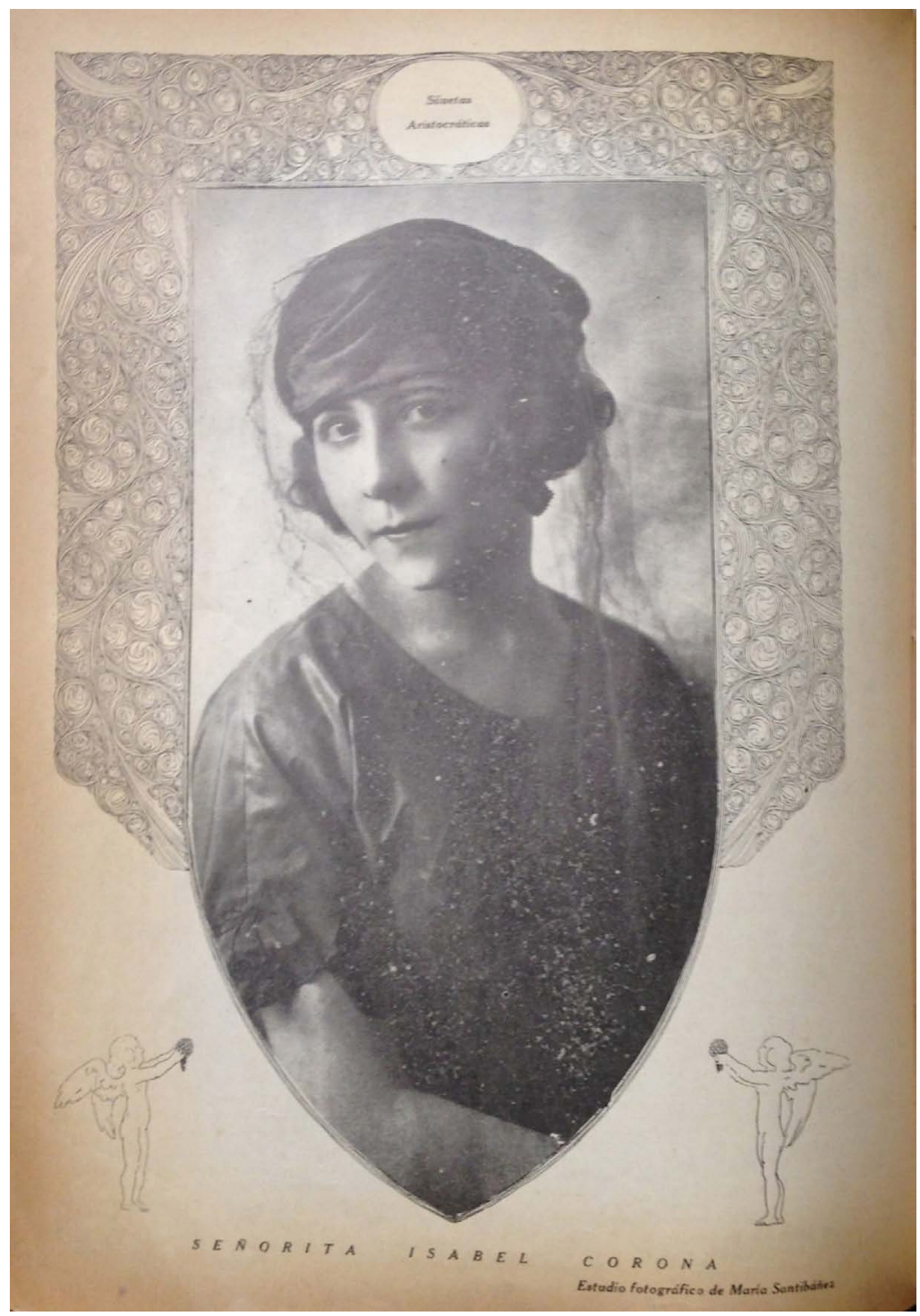

Figura 2 - María Santibáñez, "Señorita Isabel Corona”, Sección "Siluetas Aristocráticas”, El Universal Ilustrado, 3 de febrero de I92I, n. I96, p. s/n. Hemeroteca de la Biblioteca Lerdo, Secretaría de Hacienda y Crédito Público

2 En I9I9 había una sección llamada "Galería Social”; en I92I hubo dos secciones, "Siluetas Aristocráticas" y "Siluetas de Artistas Cinematográficas”; para I926 la sección se llamaba "Siluetas de la Vida Social”. 
Después de mirar estas imágenes, surgen varias preguntas. ¿Qué papel juegan las mascaradas fotográficas en las construcciones de identidades? ${ }^{3}$ ¿Cuál era el atractivo de impostar otras temporalidades en pleno siglo veinte en un país que estaba emergiendo de una Revolución? ¿Cómo responden las imágenes de temas grecolatinos a las alegorías en pinturas como las de Alberto Fuster y a la promoción que hizo José Vasconcelos desde su puesto de Secretario de Educación Pública de la lectura de los clásicos? ¿Cuál es la cultura visual de la que emergen? ¿Es este un escapismo hedonista, que como señala la nota de Jueves de Excélsior es propio de la "buena sociedad"? ¿Cómo explicamos estas pequeñas, pero recurrentes anomalías temáticas, en el imaginario fotográfico mexicano de los años veinte, sobre todo frente a los nacientes cánones nacionalistas y modernos de la fotografía directa?

La cultura visual de México durante los años veinte nos presenta un rico mosaico de imágenes que demasiadas veces se han interpretado reduciéndolas a la agenda de una historiografía centrada en lo nacional, y orientada por una muy restringida concepción de lo moderno. Como nos permiten apreciar las dos fotografías con las que da inicio este texto, en los imaginarios que circularon en la prensa ilustrada, en especial los que se refieren a los teatros de revista, el cinematógrafo y el arte, los modelos de feminidad al alcance de las mujeres en el país no se limitaron a la dicotomía entre las flappers, o "pelonas", y las indias bonitas. Es decir, las representaciones de las mujeres mexicanas modernas no se jugaron en la oposición entre modernidad y tradición, sino en una tensión constante entre versiones híbridas de diferentes tipologías femeninas. Tehuanas, chinas poblanas y pelonas se vieron acompañadas por imágenes de las estrellas del cine estadounidense, del teatro y la danza nacional, retratos de las señoritas de buena familia y una pléyade de personajes femeninos impostando identidades exóticas, pasadas o inventadas ${ }^{4}$.

Este artículo abordará varias fotografías pictorialistas realizadas por la fotógrafa

3 Como aclara Tagg (I988, p. 2), “[...] every photograph is the result of specific and, in every sense, significant distortions which render its relationship to any prior reality deeply problematic and raise the question of the determining level of the material apparatus and of the social practices within which photography takes place".

4 Flapper y pelona: nombres para designar a las "chicas modernas" de cabello corto, sombrero cloché cuyas contrapartes tradicionales fueron la "india bonita” y la mujer mestiza de clase baja. China poblana: tipo femenino del costumbrismo mexicano del siglo XIX, vestía falda con lentejuelas bordadas, blusa blanca con hombros descotados y rebozo. Tehuanas: mujeres indígenas zapotecas del Istmo de Tehuantepec (ZAVALA, 20IO, p. 5-II). Zavala (20IO, p. 7) se pregunta: “How are we to reconcile Mexican women’s urge to be modern with the countless images in murals, easel paintings, and photographs of beautiful, passive, premodern, corn-fed indias bonitas...? And how are we to account for the persistence of this imagery well into the I940s, a period when Mexican politicians declared the Revolution 'complete', and pushed Mexico toward economic, social, and industrial modernization?”. Entiendo que Zavala enfatiza esa dicotomía de forma retórica para resaltar las tensiones en las construcciones de género en la propia invención de la identidad nacional posrevolucionaria. Desgraciadamente la dicotomía entre las pelonas, como chicas modernas, y las indias bonitas como representantes de la "tradición milenaria" y la autenticidad mexicana, invisibiliza otra serie de prácticas visuales de auto-representación de las mujeres mexicanas - sobre todo en la prensa periódica y a través de fotografías e ilustraciones - que no respondían a esa dicotomía, como en el caso de las mujeres que fotografió Santibáñez. 
mexicana María Santibáñez durante la década de I920 y publicadas sobre todo en El Universal Ilustrado5. En el estudio fotográfico de esta mujer en la ciudad de México, se dieron cita en los años veinte tanto familias "bien" como actrices del teatro y cine nacional. En sus fotografías, así como en otras imágenes presentes en la prensa ilustrada de la época, encontramos las posturas e imposturas de una incipiente clase media alta, que se refugió en el pictorialismo en buena medida como escapismo de una situación política y económica compleja en las desgastantes postrimerías de la Revolución ${ }^{6}$. Estas imágenes le dan cuerpo a una serie de sentimientos, hábitos y expectativas propias de la época, vinculadas con los cambios en la presencia social de las mujeres, su papel en la cultura en espacios como las letras, la danza, el teatro y el cine y sobre todo con la fotografía como su vehículo. La existencia de una pequeña clase media mexicana fue una de las condiciones de posibilidad que hicieron factibles estas modificaciones en los roles de las mujeres y el cambio en su presencia social. Otras fueron el incremento de opciones de consumo de ciertos productos "masivos" en la ciudad, lo cual marcó con mayor fuerza la diferencia entre el campo y los centros urbanos como México y Guadalajara. Además, como señala Sara Lovera, entre I9I5 y I9I9 las mujeres que habían combatido y defendido a la Revolución se fueron integrando al proceso de pacificación y constitucionalismo, desde donde siguieron como activistas defendiendo los derechos de las mujeres en la nueva estructura del Estado (LOVERA, 20I6, p. I48). Se integraron, además, como obreras en fábricas, engrosando las filas de las clases trabajadoras. Esa presencia también afectó las percepciones que las mujeres tuvieron de su propia agencia en el periodo de reconstrucción nacional.

En este artículo reflexionamos sobre una forma de ver y fotografiar paralela a la fotografía vanguardista (considerada "realmente" moderna), para además pensar sobre algunos cambios en las experiencias de esos cuerpos femeninos disfrazados y retratados por María Santibáñez. El artilugio del disfraz y la construcción de la pose, la experiencia de posar, la gestualidad de las modelos y la experiencia de ver fotografías posadas pueden considerarse como disparadores afectivos. Así, pondremos atención en la forma en la que, en los procesos de modernización del país, las mujeres generaron su propia construcción en una suerte de espectáculo visual y al hacerlo fueron construyéndose como sujetos modernos. Además, la posibilidad de ofrecer datos biográficos de la fotógrafa, inexistentes hasta ahora, nos sirven para pensar la relación de la experiencia de vida de María Santibáñez con sus preferencias temáticas y formales.

5 Publicación semanal del diario El Universal fundado en I9I6 por Félix F. Palavicini. En sus páginas encontramos a la enorme mayoría de fotógrafos y fotógrafas que en esos años producían imágenes en México, y no pocos del extranjero (RODRÍGUEZ; LEDESMA; ÁVILA CANO, 20I6; HADATTY MORA, 20I6).

6 El desaparecido historiador mexicano Álvaro Matute nos recuerda que el presidente Porfirio Díaz en I908 había expresado al periodista James Creelman - en la famosa entrevista de I908 - que el surgimiento de una clase media que podía "sustituirlo mediante un ejercicio democrático del poder" lo hacía sentir que podía retirarse tranquilo. El surgimiento de esa clase media, si bien no era mayoritaria, "resultó lo suficientemente emprendedora para originar, encauzar y dirigir no una democracia sino una revolución” (MATUTE, 2002, p. 54-55). 
Partimos de las revistas ilustradas dado que no existe un archivo de María Santibáñez, como los hay para Lola Álvarez Bravo o Tina Modottì. En ese sentido las propias publicaciones deben considerarse como archivo específico para historiar la producción de Santibáñez y descubrir los contextos socio culturales en los que creo y circuló sus fotografías. Aunque las revistas nos permiten ver la fuerza con la que el cine comercial estadounidense impactó la imaginación femenina mexicana, no sentó modelos canónicos absolutos a seguir, ni creó un tipo "normativo" de mujer moderna (WEINBAUM, 2008; ARIZA, 20I5; HERSHFIELD, 2008; SLUIS, 20I6). Se convirtió en una fuente visual más de la cual se abrevó. A decir de las editoras de The Modern Girl around the World, una de las cosas que identifica a las chicas modernas de modo global es el uso que hicieron de algunos bienes de consumo y el erotismo explícito con el que posaron; pero en su ejercicio comparativo también descubrieron que no hay un tipo normativo de chica moderna que se derramara prescriptivamente de Europa y los Estados Unidos al resto del mundo. Más bien, valerse de las imágenes de chicas modernas como herramienta heurística sirvió a este equipo de investigadoras para descubrir cómo, para diferentes grupos sociales en distintas partes del mundo y diferentes contextos, se entendió y construyó a ciertas mujeres como "modernas" (WEINBAUM, 2008, p. II5, I47, 225).

Algunos elementos de las representaciones visuales de las chicas modernas de manera global fueron el cabello corto, las cejas delgadas, depiladas y delineadas, la boca pintada (y generalmente sonriente), el uso de ropa más bien provocativa y cuerpos alargados y estilizados (WEINBAUM, 2008, p. I3I). En nuestro país, al lado de reportajes dedicados a las modificaciones del cuerpo en esa modernidad pujante - el cuerpo ejercitado, sano, bien formado, perfumado y depilado - en las revistas ilustradas se invocaron personajes de una imaginería greco-romana que argumentaba a favor del buen gusto, el refinamiento, la gracia y en general de una contención del cuerpo a la vez que lo explayaba hacia horizontes de un imaginario social decimonónico que se desvanecía.

En las imágenes de María Santibáñez, la fotógrafa, las actrices y las mujeres de clase media, escenifican alegorías fotográficas - algunas afines al simbolismo finisecular en cuanto a temática - que les permite impostar otras identidades y otra temporalidad imaginada y al hacerlo evadirse de la retórica nacionalista para ampliar un repertorio de emotividades femeninas. A veces vestidas de gitanas, otras de exóticas Nefertitis o revestidas del mundo clásico o el dieciochesco, estas fotografías inscribían a la imagen y a sus modelos en un "buen gusto" sustentado en los valores humanistas de la educación clásica y la cultura física.

7 Lola Álvarez Bravo Archive, Center for Creative Photography en la Universidad de Arizona, Tucson en los Estados Unidos. No hay un archivo que concentre los materiales documentales y fotográficos de Tina Modotti, dispersos en archivos en los Estados Unidos, Rusia, Italia y México. 


\section{LA FOTÓgRAFa SANTIBáñeZ}

Sabemos, gracias a los trabajos de la investigadora Rebeca Monroy, que María Santibáñez inició su trayectoria en la fotografía como asistente/aprendiz del fotógrafo de estudio Martín Ortiz (MONROY NASR, 20I5, p. 38-48). La historiografía de la fotografía mexicana no había logrado concretar los datos biográficos de María Santibáñez. Como ha mostrado la investigación para este texto, esa imprecisión se debe a complejidades en la historia familiar de la fotógrafa y a que hasta la fecha no se ha encontrado ni su partida de nacimiento ni su acta de bautismo. Los archivos del Registro Civil han servido como fuente fundamental para reconstruir una pequeña parcela de la historia de vida de María Santibáñez

El 29 de abril de 1926 la fotógrafa contrajo matrimonio con Alberto Roca Cuxart, pintor, nacido en Barcelona, España. Según el acta de matrimonio, María Santibáñez nació en el estado de Oaxaca en 1895, hija legítima de Luis Santibáñez y Ángela Prieto9. Sin embargo, la revisión de los documentos nos muestra un panorama más complicado. Ángela Prieto ${ }^{\text {IO }}$ y Luis Santibáñez ${ }^{\text {II }}$, padres de la fotógrafa, tuvieron tres hijos: Enrique Leonardo (I869-I93I) ${ }^{\mathrm{I} 2}$, Lucio Adolfo (I872-I954) ${ }^{\mathrm{I3}}$ y Luis Urbano $\left(\right.$ I878-I882) ${ }^{\mathrm{It}}$ que falleció de disentería en la ciudad de Oaxaca. En el acta de defunción

8 Debo toda la información genealógica de María Santibáñez a la generosidad de mi colega del Instituto de Investigaciones Históricas de la UNAM, Dr. Javier Sanchiz Ruiz, quien ha integrado esa información a la base Geneanet, del Seminario de Genealogía Mexicana. Puede consultarse en <https://gw.geneanet.org/ sanchiz?n=santibanez+prieto\&oc=\&p=maria $>$. Se han omitido las direcciones electrónicas de documentos ya que requieren de suscripciones en las bases de Ancestry y FamilySearch, pero están disponibles para su consulta en la base de Geneanet en la referencia proporcionada en esta nota.

9 Acta de matrimonio civil de Roca Cuxart, Alberto y Santibáñez Prieto, María, 29 abril de I926, Folio 65, Partida 79. México D.F.

Io Ángela Prieto Figueroa (I850-I928); hija de José Prieto y Juana Figueroa según se asentó en el acta de bautismo de Luis Urbano Santibañez Prieto del I4 de agosto de I878. Parroquia del Sagrario, Libro de Bautismos Españoles I875-I879, página I42 vuelta, acta Iro5.

II Luis Santibáñez Azotla, no hay fechas ni de nacimiento ni de fallecimiento. Registro Civil de la Ciudad de México, Acta de nacimiento de Guillermo Santibáñez Prieto, I6 de Julio de I9I9, folio I33, acta 288.

I2 El acta de bautismo de Enrique Leonardo Santibáñez en los registros parroquiales y diocesanos (I559-I988) de la ciudad de Oaxaca, asienta que fue hijo natural de Luis Santibáñez y Ángela Prieto. Enrique Leonardo fue Cónsul General de México en San Antonio Texas de I927 hasta su fallecimiento en esa ciudad en I93I. “Enrique Santibáñez, expediente personal”, Archivo Histórico “Genaro Estrada” de la Secretaría de Relaciones Exteriores de México, 5-IO-IO-(I) años I909-I923, 255 ff.

I3 En el acta de bautismo de Lucio Adolfo Santibáñez Prieto se asienta que es hijo natural de Luis Santibáñez y Ángela Prieto. Oaxaca de Juárez, Sagrario Metropolitano de la Catedral de Oaxaca, Bautismos I87I-I874, registro I543, folio 258, 22 de diciembre, I872. Lucio Adolfo fue empleado, luego abogado y según su acta de defunción médico homeópata. Acta de Defunción, foja 9I, Partida 90, I5 de abril I954.

I4 Luis Urbano Santibáñez Prieto, Muerte 2 de agosto de I882, Oaxaca, México, Libro de Actas de Defunción I882, foja 369, registro 738 . 
de Luis Urbano, se asienta que el padre, Luis Santibáñez ya había fallecido ${ }^{15}$. Tanto María como su hermano Guillermo (I897-I972) ${ }^{16}$ nacieron más de diez años después del fallecimiento de Luis Santibáñez. Ángela debe haber procreado tanto a María como a Guillermo con otro hombre y los registró como hijos del finado para evitar el escarnio de la sociedad porfiriana. En algún momento vino con María a vivir a la Ciudad de México y registró a Guillermo en I9I9, cuando éste tenía ya doce años. Ya que no se localizó documentación del nacimiento de María, lo que otros documentos arrojan son dos fechas probables: I886 o I895. La fecha de I886 se desprende del acta de defunción de la fotógrafa. Sin embargo, fue un desconocido quien levantó el acta, guiado posiblemente por su percepción de la edad avanzada de María, a falta de documentos que revelaran su fecha de nacimiento ${ }^{\mathrm{I}}$. En cambio, la fecha de nacimiento de 1895 se desprende de la edad que la propia María asentó en el acta de matrimonio civil, 3I años al 29 de abril de I926 $6^{\text {I8 }}$.

El juego de mascaradas, como vemos, inicia con el maquillaje de documentos que se efectuaba para proteger a los hijos de la posible condena de la sociedad porfiriana. Luego la fotógrafa convertiría el disfraz en una estrategia visual.

Pero además hay otras cosas importantes que se desprenden de los documentos. Por ejemplo, en el acta de matrimonio nuestra fotógrafa declara como profesión ser "artista fotógrafo"; se autodefine como sujeto moderno a partir de su trabajo, hecho sobre el que insistió al firmar a mano las fotografías que realizó, al igual que sus colegas hombres. Santibáñez se incorporó a la vida laboral a los doce años y hacia I9I3 - cuando tenía I8 años - debió ingresar al estudio de Martín Ortiz con quien trabajó siete años. Entre

I5 Los hijos naturales son aquellos cuyos padres son solteros o divorciados y que no se encuentran casados, por el civil o por lo religioso, al momento del nacimiento del producto.

I6 Guillermo Santibáñez Prieto nació en la Ciudad de México, Registro Civil de la Ciudad de México, registrado el I6 de Julio de I9I9, folio I33, acta 288 nacido el 5 de mayo de I897. Falleció en la misma ciudad el I8 de mayo de 1972.

I7 Acta de Defunción 30I, Partida Núm. 300 Santibáñez viuda de Roca María, I2 de noviembre de I966. En el acta el desconocido declara que María tenía 80 años al momento de fallecer.

I8 Acta de Matrimonio entre Roca Couxart Alberto y Santibáñez María, 29 de abril de I929, Folio I65, Partida 79, México Distrito Federal, Matrimonios, I86I-I950. La información matrimonial ingresada el Io de abril de I926 en el Sagrario Metropolitano del Distrito Federal, en un documento presenta una tachadura donde sobre el “ 5 ” de 35 (años) para la edad de María se corrigió con un “o”. Así el acta de matrimonio religioso indica que tenía 30 años, y no 3I, como se declaró en el acta del matrimonio civil, error o maquillaje eso ya levanta ciertas sospechas. En la documentación para el matrimonio religioso María declaró que fue bautizada el 28 de julio de I895 en la Parroquia de Santa María del Tule, Oaxaca. Esa acta no ha sido localizada. Parroquia del Sagrario Metropolitano de México, documento sin número, Información Matrimonial de D. Alberto Roca y Cuxart y de Dña. María Santivánez (sic), recibida en la Parroquia del Sagrario el día Io de abril de I926 por el señor cura de la misma, Don Carlos Villegas Cruz. 


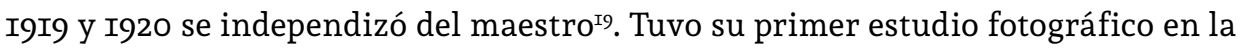
calle de Bolívar no. 22, el cual casi tiene que cerrar por falta de ingresos. Para I920, participó en un certamen de fotografía convocado por El Universal Ilustrado y ganó el primer lugar con lo que logró salvar el estudio de la banca rota. Con el premio también incrementó su clientela. El año de su matrimonio, I926, el fotógrafo Antonio Garduño la demandó por no haber pagado el importe de las fotografías que hizo de la boda. Entre septiembre y octubre de I926 la demanda se desenvolvió en los juzgados y al final María pagó a Garduño la exorbitante cantidad de doscientos pesos por las fotografías ${ }^{20}$. Desgraciadamente el expediente no contiene las imágenes que estaban anexas al caso, ni se encuentran éstas en la fototeca del Archivo General de la Nación.

Para I927, la fotógrafa ya había mudado el estudio a la calle de Ave. Juárez No.62 y retrataba a la alta burguesía mexicana, así como a famosas actrices nacionales. Ese año se desencadenaron una serie de pérdidas familiares que tal vez explican cierta melancolía en sus imágenes; en I927 perdió una hija, en I928 falleció su madre, en I929 perdió un hijo de dos días de nacido y en I93I a su hermano Enrique ${ }^{21}$. Si bien siguió fotografiando durante la década de los treinta, ahí perdemos su rastro en las publicaciones periódicas ${ }^{22}$. Hay pocas imágenes vintage circulando entre coleccionistas, y la “obra” de esta mujer hay que rescatarla en la hemerografía.

\section{RETRATAR Y APARECER}

En I920, el pintor Carlos Mérida publicó en El Universal Ilustrado una nota sobre los fotógrafos retratistas en México. Quiero llamar la atención sobre los comentarios que hace de las imágenes de María Santibáñez:

[...] Hoy nuestros retratistas han observado el movimiento de los studios extranjeros y, amén de profundizar el conocimiento de los claroscuros y los contrastes de negro y blanco, intentan ofrecer un pequeño esbozo espiritual en la fotografía que, hasta ahora, era la simple reproducción de los rasgos físicos de los individuos.

I9 En la entrevista ofrecida a la revista Mujer en I927, Santibáñez dice "Comencé a trabajar a los doce años de edad. Al lado del señor Ortiz trabajé siete años”. Si leemos bien lo declarado, no afirma haber entrado a los doce años a trabajar con Ortiz, sino que se incorporó a la vida laboral a esa edad. Si tomamos por buena la fecha de nacimiento de I895, empezó a trabajar en el estudio de Martín Ortiz en I9I3, cuando la fotógrafa tenía I8 años (RÍOS CÁRDENAS, I927, entrevista atribuída, transcrita en RODRÍGUEZ, 20I2, p. I80).

20 “Juicio oral de Antonio Garduño G. contra María Santibáñez 27 septiembre I926", AGN Galería 6: Tribunal Superior de Justicia del Distrito Federal/Siglo XX/Archivo Histórico I/I926/ Caja 2049/ TSJDF Folio: 37358I, 27 de septiembre de I926, 5 fojas.

21 Acta de Defunción 30I, Partida Núm. 300 Santibáñez viuda de Roca María, I2 de noviembre de I966. Enterrada en el Panteón Español. Sobre la hija fallecida véase María Ríos (I927), reproducido en Rodríguez, 20I2, p. I80.

22 Sobre Santibáñez han escrito: Monroy, 2000, p. 39; Monroy, 2005; Torrez, 20II; García Krinsky 20I2, p. I6, 95-97; Rodríguez, 20I2, p. 38, 44-56; Córdova, 20I2, p. 58-79; Ávila Cano, 2016. 
[... ] Hay tanto arte hoy en las galerías de María Santibáñez, Smarth, Silva, Martín Ortíz y demás caballeros de la lente, como en los salones de la Academia.

[...] María Santibáñez es indiscutiblemente la retratista de la mujer...

[...] María Santibáñez nos dice que la mujer se presta más que el hombre a especulaciones artísticas en el campo de la fotografía y a ese respecto creemos que ella no tiene toda la razón, si consideramos que su labor está supeditada a la necesidad de trabajar determinados modelos; más bien creemos que sea una necesidad espiritual en ella el buscar, en determinados sujetos, la resolución artística de ciertas ideas y emociones.

De ahí su predilección intuitiva por la mujer...

[...] La fotografía moderna nos muestra ya estados del alma, caracteres, aspectos anímicos...

[...] Con una educación de verdadera estudiosa ha seguido paso a paso la evolución de los artistas universales de la cámara y a ello se debe que sin haber salido de México esté a la altura de cualquier fotógrafo del mundo. Conoce a Stieglitz, Abbé, a Henry Manuel, de París. (MÉRIDA, I920).

El texto de Mérida nos permite apreciar un fragmento de la recepción de la fotografía pictorialista en esos años y nos sirve como pre-texto para pensar sobre la eficacia y vitalidad de estas imágenes fotográficas; su poder. Llama la atención que Mérida supone que hay un "esbozo espiritual" en la fotografía pictorialista, y que éste se debe en parte al seguimiento que hicieron los fotógrafos mexicanos del trabajo de los estudios de los fotógrafos extranjeros; que señale que Santibáñez es "indiscutiblemente la retratista de la mujer" y por último que la fotógrafa posee una necesidad espiritual que la hace buscar en sus modelos la resolución artística de ciertas ideas y emociones, que por cierto en ella son "intuitivas”. Si se trata de una intuición, creo que más bien Santibáñez la tenía sobre la expectativa tanto de sus modelos como de la propia prensa y sus lectoras. Es decir, se trataba de una buena intuición comercial y no de una propiedad innata de sensibilidad particular debida a su condición de mujer.

Respecto a las "emociones" expresadas en las imágenes, de seguro se vinculaban más con la imitación de una gestualidad presente en las imágenes de las actrices, tanto del cine estadounidense como del teatro de revista y cine nacionales. Para el horizonte histórico de Santibáñez, como bien afirma el historiador Carlos A. Córdova (20I2, p. 64), "Lo que Mérida tenía frente a los ojos eran los esfuerzos hacia un nuevo retrato, que se fundamentaba menos en la mímesis y la fotogenia, para apoyarse más en la seducción o la estilización”. Estos artilugios estilizados y seductores chocaban de lleno con los proyectos de la fotografía directa (como no posada) que terminaron por convertirse en las formas hegemónicas privilegiadas por la vanguardia fotografía en México.

Las apariciones femeninas en la prensa ilustrada, también nos sirven para comprender la forma en la que se fue constituyendo un campo moderno de visibilidad. Como afirma Liz Conor para el caso de las tipologías de mujer moderna en Australia en los años veinte, hay más en el fenómeno de convertir a la mujer en "espectáculo" - ella lo llama la espectacularización de las mujeres - que el hecho de su cosificación, más que la constante y absoluta pérdida de auto-determinación con la que estas "apariciones espectaculares" se asocian (CONOR, 2004, p. 3). Conor propone utilizar el término "aparición” (appearing) como alternativa para investigar 
"el impacto de las representaciones visuales de las mujeres en la producción de una nueva subjetividad femenina moderna” (CONOR, 2004, p. 3). Según Conor, estas "apariciones en imagen" alteraron la categoría "mujer" en formas que trastocaron la relación entre la visibilidad de las mujeres y la producción de posiciones para los sujetos femeninos. Es decir, eso que puede parecer una paradoja, el convertirse en espectáculo (objeto de la mirada) termina produciendo una posición del sujeto femenino moderno en tanto "mujer moderna" (agencia de un sujeto particular marcado por una historicidad y una serie de decisiones que se van tomando en la adopción de la pose). Así, estas mujeres que se "producen" a sí mismas para la prensa, al llevar a cabo un acto performático en ese construirse-y-aparecer, ejercen una capacidad de concitación que va más allá de un “devenir imagen” o "devenir objeto".

La filósofa feminista Judith Butler ha utilizado el término "aparecer” al lado del término "mascarada" como instrumentales en la performatividad del género. En Gender Trouble, Butler explica, además, que la performatividad no se constituye de "un" acto aislado, sino de una "repetición y un ritual" (BUTLER, I990, p. XV)²3. Así, podemos decir que cierta "expectativa" de lo que es o puede ser femenino se constituye en las reiteraciones de las poses fotográficas. De ahí que una entre muchas cosas que aportan estas imágenes en la prensa, es un acceso a las maneras en las que la visualidad - lo que se puede ver, lo que merece ser visibilizado - se va constituyendo.

En los casos que aquí presentamos, también podemos apreciar la forma en la que estas mujeres no solo "aparecen" constituyéndose como sujetos con un género, sino también como miembros de una clase social que también ponen en acto ${ }^{24}$. En lo que toca a la fotógrafa, su agencia es indudable en la escenificación, la iluminación, el encuadre y foco y la impresión de las imágenes y su entrega a la clientela. También tiene que ver con la mascarada que María parece haber vivido respecto a sus orígenes y que los documentos revelan como un proceso de ocultamiento/reconstrucción.

\section{EL REgRESO DEL CLASICISMO}

En las siguientes tres fotografías los retratados se encuentran disfrazados con vestimentas que evocan escenas greco-romanas y en el attrezzo se incluyen túnicas - a modo de quitones, peplos e himationes - guirnaldas de flores, sandalias, cántaros de barro y fondos difusos. En la fotografía tomada de la publicación Jueves de Excélsior de I923 (Figura 3) y realizada por Foto Star, asistimos a unos "Bailes clásicos de la buena sociedad tapatía”. Por “buena sociedad” se alude ahí a las clases pudientes de la ciudad de Guadalajara, estado de Jalisco. Se trata del registro fotográfico de un recital

23 Butler complejizó el proceso posteriormente en: Butler, 2002, p.I2-I5.

24 Es posible pensar en la clase y el género como construcciones que se constituyen y sostienen a través de actos performáticos. Sin embargo, como la propia Butler expresa, el tema de la "raza” o más bien "lo racial”, en tanto objeto de una crítica postcolonial o decolonial y anti-racista, tiene dimensiones que no permiten, o hacen sumamente problemática su reducción al concepto de performatividad. 
de danza, seguramente inspirado en la danza libre impulsada por Isadora Duncan en la segunda década del siglo $\mathrm{XX}^{25}$.

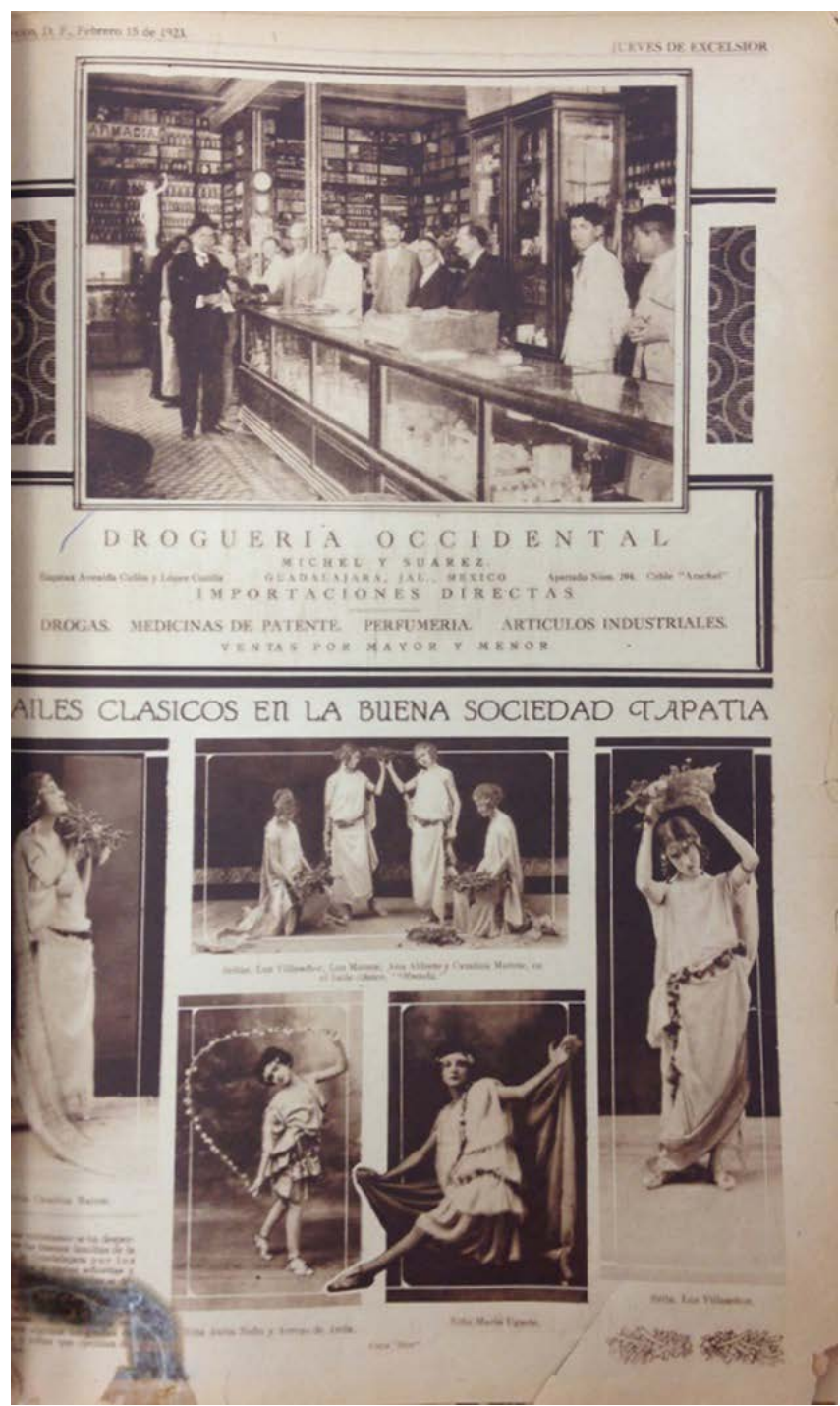

Figura 3 - Foto Star, "Bailes clásicos en la buena sociedad tapatía”, Jueves de Excélsior, febrero I5, I923, s/p. Hemeroteca de la Biblioteca Lerdo, Secretaría de Hacienda y Crédito Público

25 Ya desde I9I7 Eduardo Pastor montaba coreografías, en propuestas como "Los misterios de Afrodita" y para I9I8 Norka Rouskaya ofrecía en el Teatro Arbeu “La primavera” de Grieg, que a según Alberto Dallal (I995, p. 139), "le entraba de lleno y con regocijo al neoclasicismo”. Otro ejemplo proviene de la promoción que la prensa hizo de temas grecorromanos en el cine estadounidense, como por ejemplo en la película "Hombre, mujer y matrimonio" (I92I) El Universal Ilustrado, México, n. 242, 22 de diciembre de I922: p. s/n. 
En dos fotografías realizadas por María Santibáñez, nos encontramos primero con el retrato de la actriz Graciela de la Lara, publicado en la portada de El Universal Ilustrado el 29 de abril de I920. Es la fotografía premiada en el concurso de El Universal ganado por Santibáñez (Figura 4): una joven sentada en primer plano y envuelta en un paño abate la mirada y evita nuestros ojos afectando una pose extraña con su mano derecha colocada en una incómoda posición que enfatiza nuestra apreciación de que se trata de una postura forzada. Detrás de ella podemos ver el fragmento de una balaustrada sobre la que descansa una olla de barro. El fondo se nos pierde en la imprecisión nebulosa.

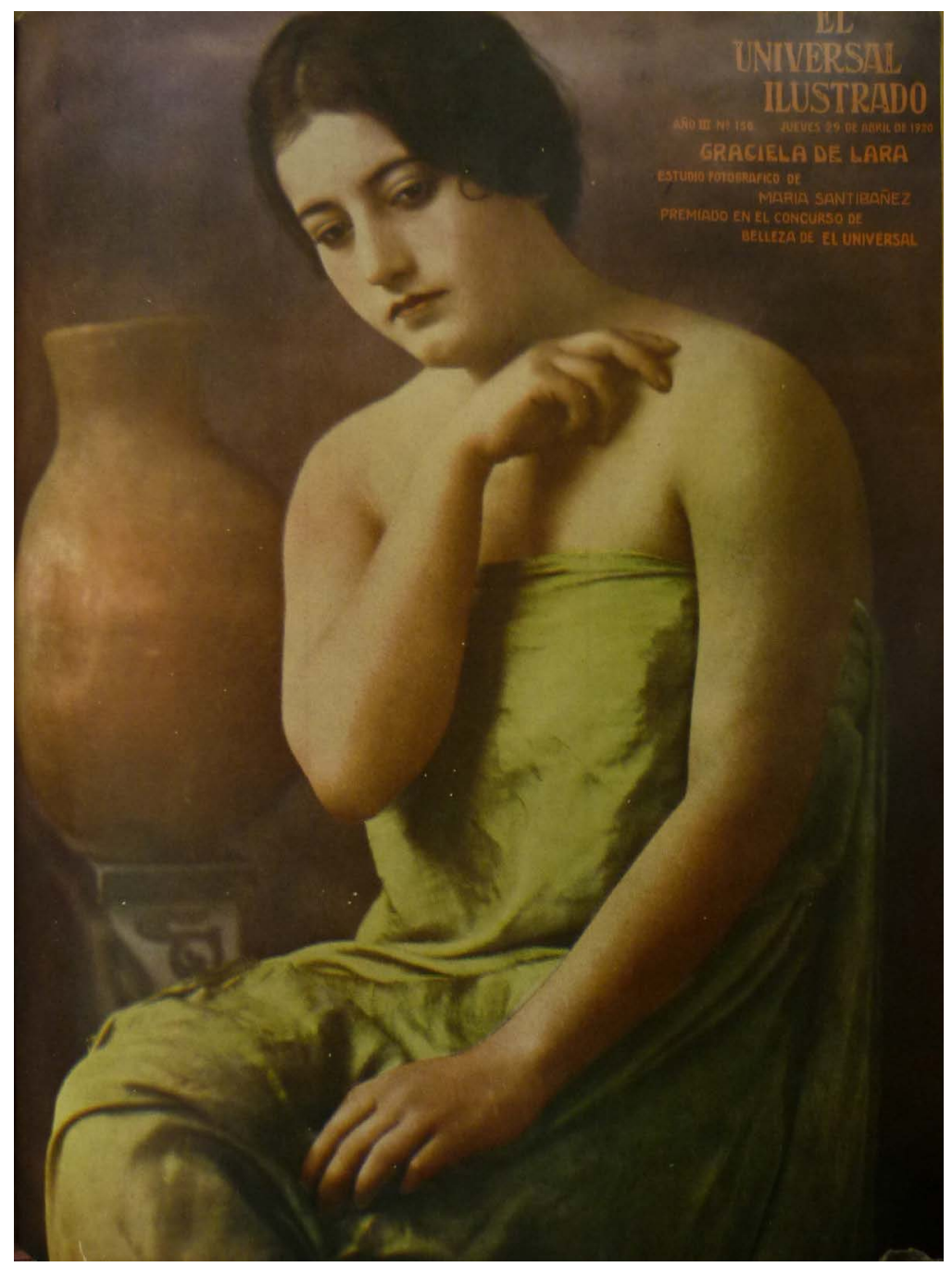

Figura 4-María Santibáñez (fotógrafa), Graciela de Lara, en El Universal Ilustrado, año III, n. I56, 29 de abril de I920. Hemeroteca de la Biblioteca Lerdo, Secretaría de Hacienda y Crédito Público 
En la otra imagen de Santibáñez se repite la idea de la combinación de la retratada con una pieza de barro (Figura 5). Ella también desvía su mirada hacia el interior del jarro por lo que sus bien definidos párpados parecen estar casi cerrados. La ensoñación aparece aquí como ese lugar de fuga al que no tenemos acceso, aunque quizás se refiera a la propia escenificación o mascarada como parcela de la imaginación de la modelo y la fotógrafa. De mayor definición que la primera, esta imagen también resalta la estética pictorialista que suscribía en estos años Santibáñez. Más que un alto contraste pronunciado, que definiría en parte la característica formal de la fotografía directa, considerada de vanguardia, esta otra forma de fotografía moderna en México resaltó el espectro amplio de grises, trabajados para crear elegantes claroscuros a la vez que favoreció un foco suave.

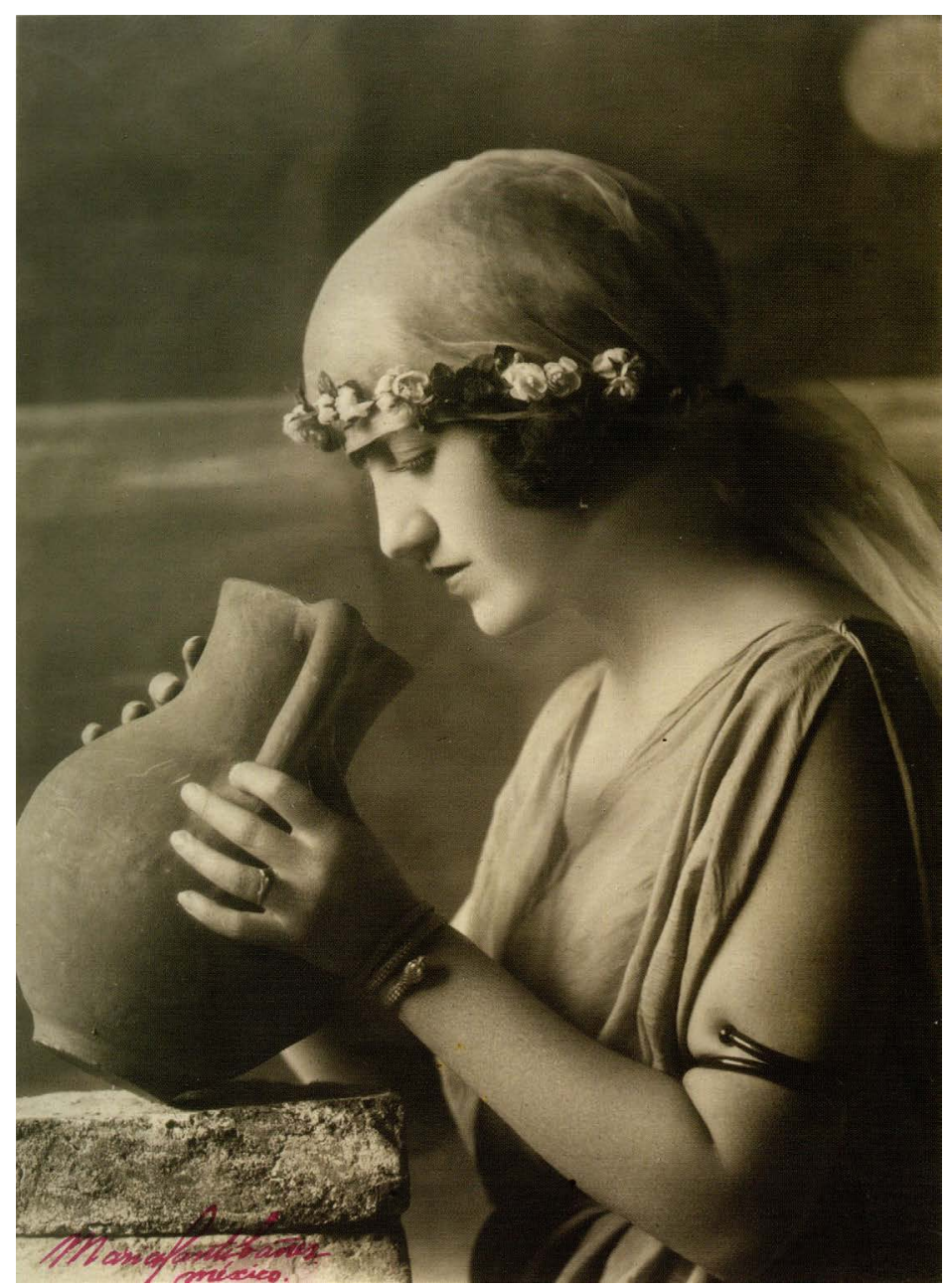

Figura 5- María Santibáñez, “sin título”. Col. Fotográficas Fundación Televisa, tomado de GARCÍA KRINSKY, Emma Cecilia. Mujeres detrás de la lente.Ioo años de creación fotográfica en México I9Io-20Io. México: Conaculta, 20I2, p. 97 
Sin embargo, en el encuadre compartió una característica con esas fotografías más afines a los trabajos que Edward Weston y Tina Modotti pusieron de relieve a mediados de los años veinte, en especial el recorte del cuerpo no necesariamente centrado en la composición a diferencia de las imágenes de estudios fotográficos decimonónicos. Hay además en las fotografías modernas un esfuerzo por retratar mujeres que proyecten una cierta vida interior: los ojos entornados mirando al cielo, como en una plegaria, los párpados casi cerrados que podemos imaginar cubren una mirada que explora "la profundidad" (del cántaro, de los sueños propios o bien del consumo y las mercancías). Un giño simbolista ajeno al gusto de la imagen de vanguardia.

Historiadores del arte como Aby Warburg, y George Didi-Huberman (siguiendo a Warburg), se han detenido a ponderar el posible significado de la supervivencia de ciertas iconografías y la manera en la que sus significados se reactualizan en cada aparición. Warburg investigaba cómo ciertas figuras parecen tener una "vida posterior" a su vida original (Nachleben) y Didi-Huberman pregunta si sus reapariciones son espectros o fantasmas que emergen en las tramas de la historia y de la producción artística (WARBURG, 2005; DIDI-HUBERMAN, 2009, p. I-30). Preguntábamos más arriba por qué a las clientas de Santibáñez podría haberles interesado retratarse disfrazadas en peplos e himationes y a qué práctica socio cultural podía responder este tipo de imágenes. Adelanto abajo algunas posibilidades.

Para los años veinte en México se ponían en juego en estas fotografías por lo menos cuatro horizontes. Primero una tradición pictórica modernista-simbolista, como en las obras de Alberto Fuster, que antecede a la obra de Santibáñez por una década ${ }^{26}$. Al igual que los orientalismos de corte romántico relanzados durante el decadentismo, esta particular nostalgia podría provenir de una desilusión con la tecnificación de la vida, el desencanto con la modernización y para México en particular debido a los horrores de la Revolución de los que tanto se ocupó José Clemente Orozco en series como "Los horrores de la Revolución” (I926-28) (INDYCH, 200I). La literatura modernista hizo eco de este gusto por lo grecorromano, como se puede leer de la pluma de José Juan Tablada, por ejemplo, quien dedica unos versos al atuendo de las mujeres griegas en "El Último Ícono" publicado en I9oo en la Revista Moderna, con una ilustración de L. Izaguirre que remite, sin duda, a la formación de los alumnos de la Academia y la copia de relieves en yeso y estampas clasicistas (Figura 6). En esta mascarada helenista, se perfila con claridad un rasgo propio de la modernidad mexicana en la que alternaron tehuanas decó, chinas poblanas con zapatillas de ballet, flappers, gitanas, odaliscas y mujeres a la greco-romana.

26 Alberto Fuster (I877-I922). Disponible en: 〈http://museoblaisten.com/Artista/I73/Alberto-Fuster > Consultado el 28 de marzo de 2018 . 


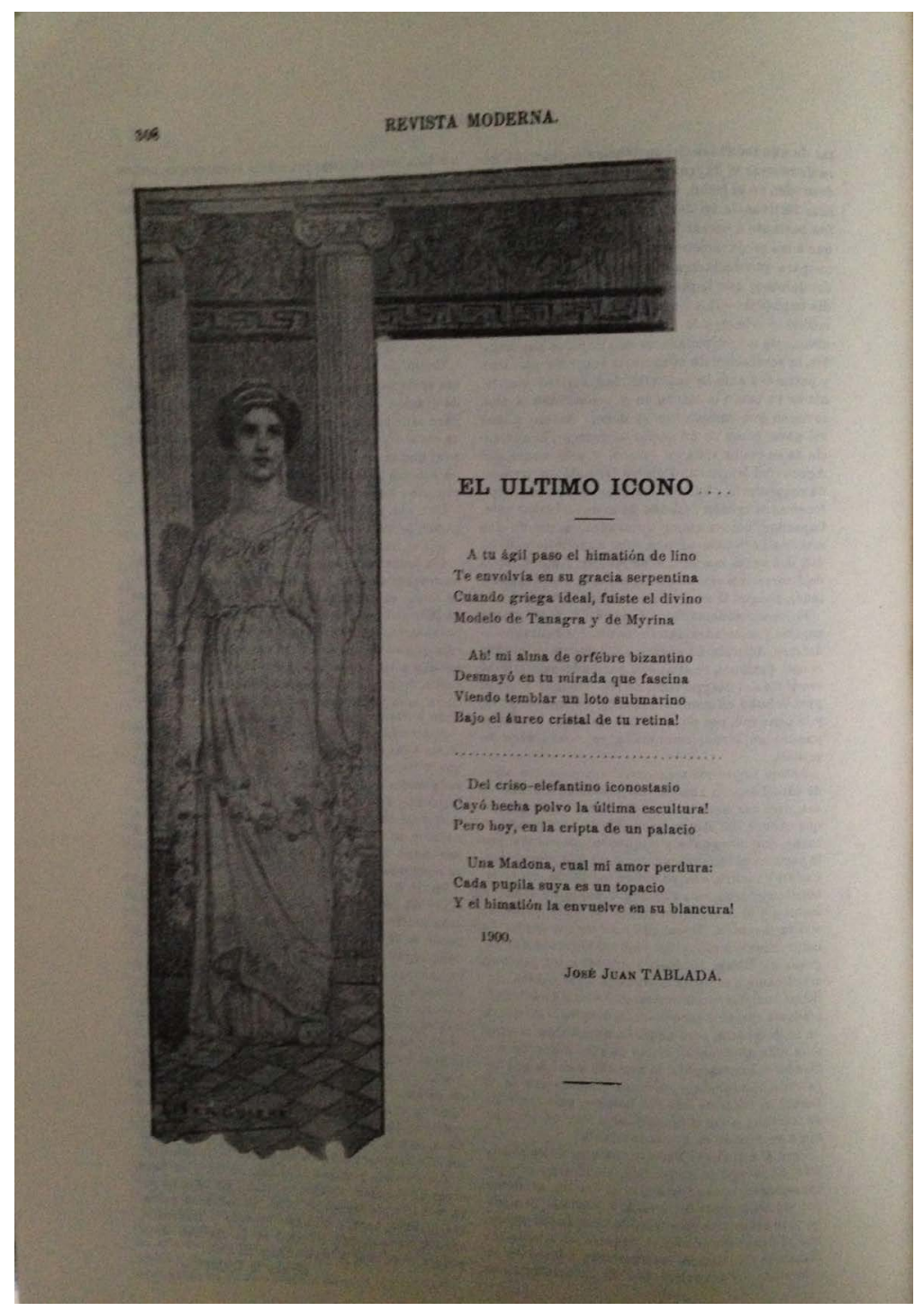

Figura 6 - José Juan Tablada, "El último ícono”, Revista Moderna, Arte y Ciencia, año III, n. 20, octubre I900, p. 308. (Ed. Facsimilar v. III) Dibujo firmado L. Izaguirre

En segundo lugar, recordemos que la política cultural de José Vasconcelos al inicio de los años veinte y desde su puesto como Secretario de Educación Pública ensalzó la importancia de acercar a los niños a la cultura y literatura clásicas para elevar sus espíritus (AA.VV, I924). No por acaso, como resalta Álvaro Matute, los ateneístas resultaron verdaderos maestros: "enseñaban para formar ciudadanos, crear una polis nacionalista, iberoamericana, con sus raíces hundidas en Atenas, en las creaciones dantescas, en Cervantes. Una polis sustentada en un demos bien formado, sólido y capaz de tomar mejores decisiones” (MATUTE, 2002, p. 54).

Pero este anhelo de elevar la cultura nacional a mejores niveles (europeos) se 
vehiculizó desde el porfiriato a través de los bailes, obras teatrales y concursos de declamación en los festivales escolares por lo que formó parte de una corriente más popular aprehendida por la comunidad escolar de padres, maestros y niños desde inicios del siglo XX. Vasconcelos capitalizó mejor de este gusto por lo clásico mediante el uso de una propaganda de Estado más modernizada, como fueron los libros editados por él en la SEP y los murales producidos en la Preparatoria Nacional durante los primeros años de su gestión. Se trataba de otros espacios de visibilización más masivos y también menos modestos que los festivales escolares del porfiriato. Eso lo apreciamos en el primer mural primer de Diego Rivera, "La Creación" (I922), pintado en el anfiteatro Simón Bolívar en San Idelfonso (Escuela Nacional Preparatoria) pletórico de figuras femeninas alegóricas y en sus murales en la Secretaría de Educación Pública (GONZÁLEZ MELLO, 2008).

En tercer lugar, le debemos este auge del clasicismo al influjo de la fotografía de los clubes pictorialistas europeos y norte americanos, en particular del trabajo de fotógrafos como Gertrude Käsebier o George Henry Seeley que la fotógrafa pudo haber observado en la revista de Stieglitz Camera Work que circulaba en México en los años que ésta trabajaba aún con Martín Ortiz, como sugiere Carlos Mérida en la nota que citamos más arriba. Seeley realizó composiciones con mujeres y piezas cerámicas en las que la ambientación nebulosa envuelve a sus mujeres en una contemplación poco mundana. Se trata de un último aliento de la estética del modernismo (como simbolismo) y un arranque de la estética moderna ${ }^{27}$.

Finalmente, se trata también de una cultura visual compartida con otros países en el periodo de entreguerras que veía en la antigüedad grecolatina la esperanza de un resurgimiento humanista y la reafirmación de un buen gusto apegado a la tradición clasicista, un "llamado al orden" antes de que a nivel formal éste fuera cooptado por el fascismo y los regímenes totalitarios. Este giro se aprecia en la pintura, la escultura, la ópera, el teatro, el cine y la danza, y fortalecía también la asociación del imaginario clasicista con un imaginario clasista (SILVER, 20Io).

\section{LAS CHICAS MODERNAS Y LAS NUEVAS MUJERES}

Es posible que una de las razones por las cuales se ha despreciado el papel que jugaron los imaginarios fotográficos y gráficos de las revistas en la construcción de modos de representar lo femenino y de visualizar a las mujeres tenga que ver con la forma en la que se construyó la teoría de las vanguardias en las que la dicotomía entre industria cultural (arte popular, cultura de masas) y estética (arte culto) marcaron al periodo del arte moderno. Andreas Huyssen lo explica con mucha claridad cuando habla de ese golfo artificial, refiriéndose a éste como el Great Divide (HYUSSEN, I986). En esa gran división, la fotografía de prensa, como un modo de darse de la cultura de masas, definitivamente había quedado excluida del relato de las historias del arte canónicas. Para restaurar una perspectiva más compleja de la visualidad del periodo posrevolucionario en México es indispensable reconsiderar esas imágenes pues en su masividad educaron la mirada del

27 En México modernismo y arte moderno no significan lo mismo. Véase: Eder, 200I. 
público lector y del analfabeto que acudía a escuchar la lectura de artículos y noticias en diferentes espacios públicos de socialización como cantinas, cafés y fondas.

Uno de mis argumentos sobre las fotografías de mujeres que realizó Santibáñez en los años veinte, yace en la insistencia sobre los cambios en una suerte de ethos femenino de esa década. Especialmente en las alternativas variadas y más múltiples de modelos de feminidad al alcance de las mujeres. La cobertura que recibieron en las revistas ilustradas los espectáculos cinematográficos, teatrales y dancísticos permiten también guiar nuestra impresión del sentir de esa década de los veinte respecto al lugar del cuerpo, la corporalidad y lo "femenino" y la manera en que esas experiencias, sus expresiones y representaciones se jugaron en las fotografías que la propia prensa diseminó. El eclecticismo, seguramente, es lo que nos hace titubear sobre el sentido que las imágenes de las mujeres fueron adquiriendo. A las mujeres de clase media y alta se les presentó un abanico de posibilidades imaginativas para "aparecer" y construirse una imagen, representarse y en la escenificación de sí mismas desplegar la agencia que las nuevas condiciones de posibilidad sociales y culturales les acercaban.

El trabajo de Conor sobre las tipologías de mujeres modernas en la cultura visual australiana me ha permitido reflexionar sobre las coincidencias y las diferencias en estos tipos femeninos que se jugaron en la espectacularización de las mujeres. Conor detecta en la prensa australiana ciertas tipologías de mujeres: la mujer de negocios (bussines girl, refiriéndose más a la mujer que trabaja en una oficina que a una empresaria en el sentido que bussines woman tendría ahora); la flapper; la screen-struck girl (aficionadas del cinematógrafo que emularon a las figuras femeninas en el cine); la participante en concursos de belleza (Beauty Contestant) y el maniquí. No pretendo hacer una selección mexicana de tipologías, pero sí insistir, al igual que Conor, que, dado que en la modernidad se intensificó la escena visual y en ella se hizo espectáculo de las mujeres, es en ese campo que podemos encontrar cómo se pusieron en acto las subjetividades femeninas (CONOR, 2004, p. XV). Es decir, revela formas de modernidad que no responden al modelo de UNA modernidad única.

La alegoría fue un recurso pictórico que se actualizó mucho en los años veinte en México en parte por la entrada de la temática nacionalista y popular, pero también porque los sentidos tradicionales de las alegorías se hicieron más opacos ${ }^{28}$. Para artistificar sus fotografías, Santibáñez alegorizó a las mujeres por lo que las vemos representando a una bacante, en una fotografía que evoca más un anuncio comercial en el que llama la atención la desproporción de las uvas que cuelgan del cabello de la modelo (Figura 7), pero que recoge eso que Mérida identifica como las enseñanzas de fotógrafos como Stieglitz en la época de la Photo-sessesion. La consigna es sencillez y elegancia, que le viene bien a un público que reafirma una posición social después de la Revolución, aún desnuda del nacionalismo posrevolucionario más populista. Una inclinación por lo escenificado que proviene del teatro de revista y el cine, también se despliega en las fotografías de Santibáñez, que de seguro surgía de la complicidad

28 Así ocurrió en la obra de pintores como Saturnino Herrán, Alberto Fuster, Roberto Montenegro y Ángel Zárraga (GONZÁLEZ MELLO, 2008, p. 2I-II4). 
con las actrices como en los casos de los retratos que hizo de Mercedes Navarro y Gilda Chavarri' ${ }^{29}$ (Figura 8).

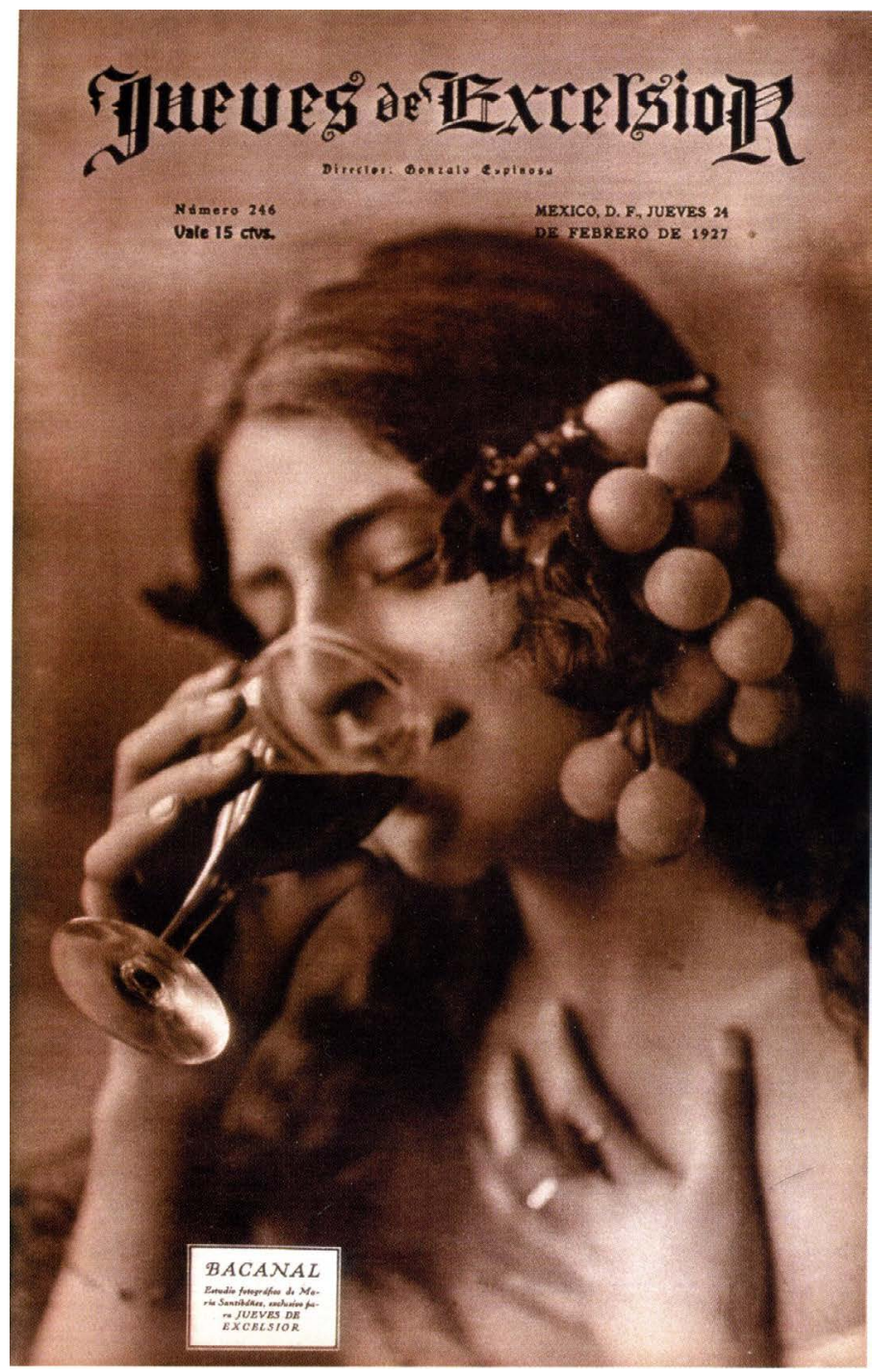

Figura 7- María Santibáñez, "Bacanal” en Jueves de Excélsior, México, n. 246, jueves 24 de febrero de I927, portada, impresión fotomecánica. Colección Julio Romo Michaud, en Rebeca Monroy, "Del medio tono al alto contraste: La fotografía mexicana de I920 a I940" en: GARCÍA KRINSKY, Emma Cecilia (Coord.). Imaginarios y fotografía en México I839-I970. Barcelona: Lunwerg editores, 2005, p. I27

29 Por ejemplo, Silva ofrece un muestrario fotográfico de poses para tragedias griegas en "A la manera del Vieux colombier", fotografías de Gilda Chavarri por Gustavo Silva en El Universal Ilustrado, México, I7 de marzo de I92I, p. 2I. 


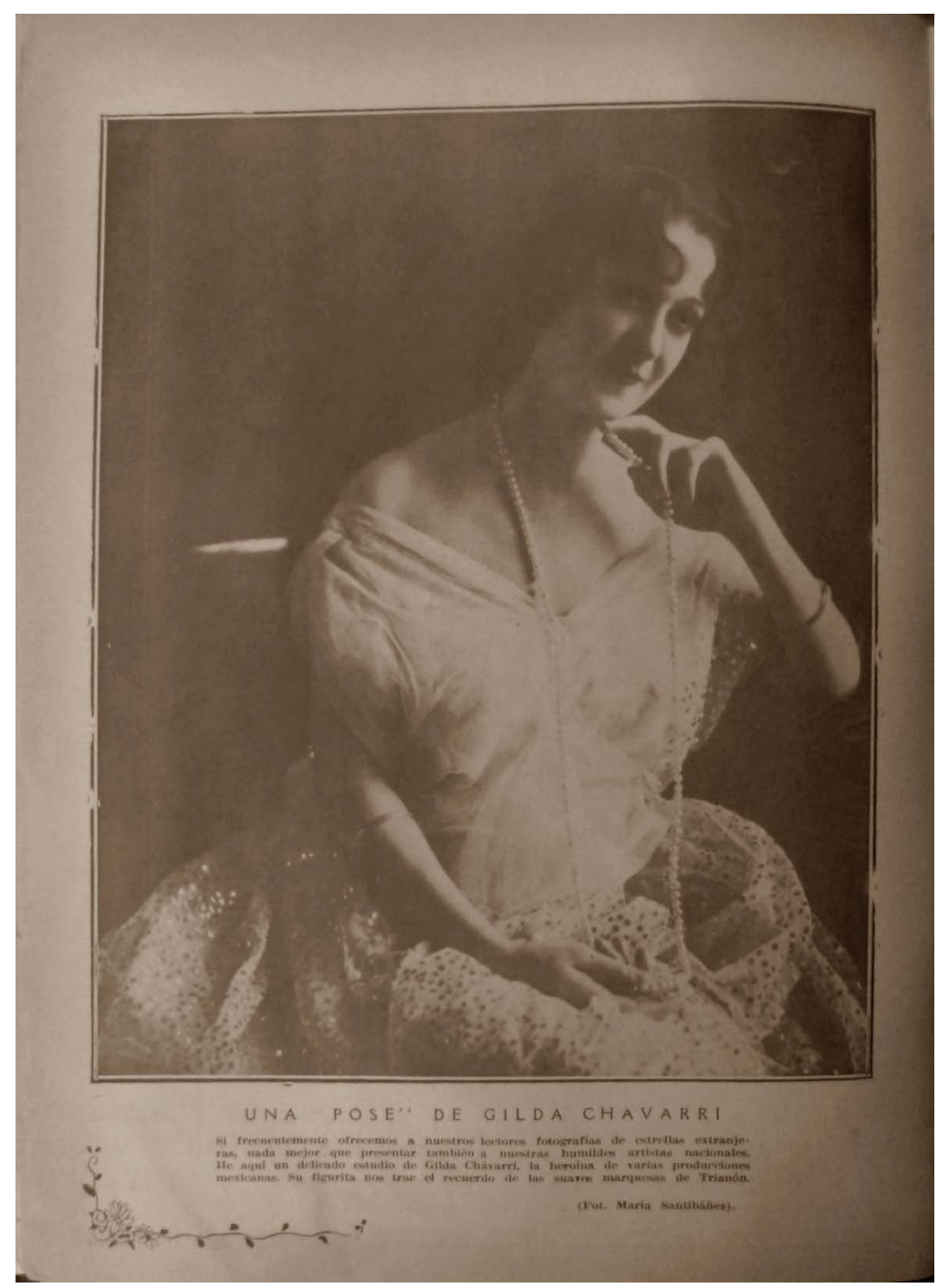

Figura 8 - María Santibáñez, "Una pose de Gilda Chavarri”, El Universal Ilustrado, año V, n. I93, I3 de enero de I92I, p. s/n. Hemeroteca de la Biblioteca Lerdo, Secretaría de Hacienda y Crédito Público

No hay que olvidar, que en la definición de la fotografía como arte en el México de los años veinte, no se aplicaba el estigma que Stieglitz prodigó a las fotógrafas comerciales, autoproclamadas artistas, que como Gertrude Käsebier ejercieron la práctica profesional (HERMANSON MEISTER, 20Io, p. I27-I28). Había que comer, pagar la renta y mantener actualizado el mobiliario del estudio. Santibáñez se concebía a sí misma como artista pero vivía de su arte. Es paradójico entonces que, en la entrevista a Santibáñez de I927, afirme que ella no comerciaba con su arte, si de hecho fue ese comercio el que le permitió mantener su independencia (RÍOS CÁRDENAS, I927, transcrito en RODRÍGUEZ, 20I2, p. I80). Y es de este caudal de 
imágenes de estudio realizadas para familias y resguardadas en álbumes y cajas de zapatos (otros tipos de archivo), donde encontraremos otra faceta del trabajo fotográfico de Santibáñez.

Dos muestras para concluir, fotografías de la familia Ruiz-Suárez y de los niños Arreola que difieren tanto en su factura. La primera (Figura 9), sobria, con un telón de fondo que simula la sala de una casa, actualiza el attrezzo de interior doméstico de clase media y media alta.

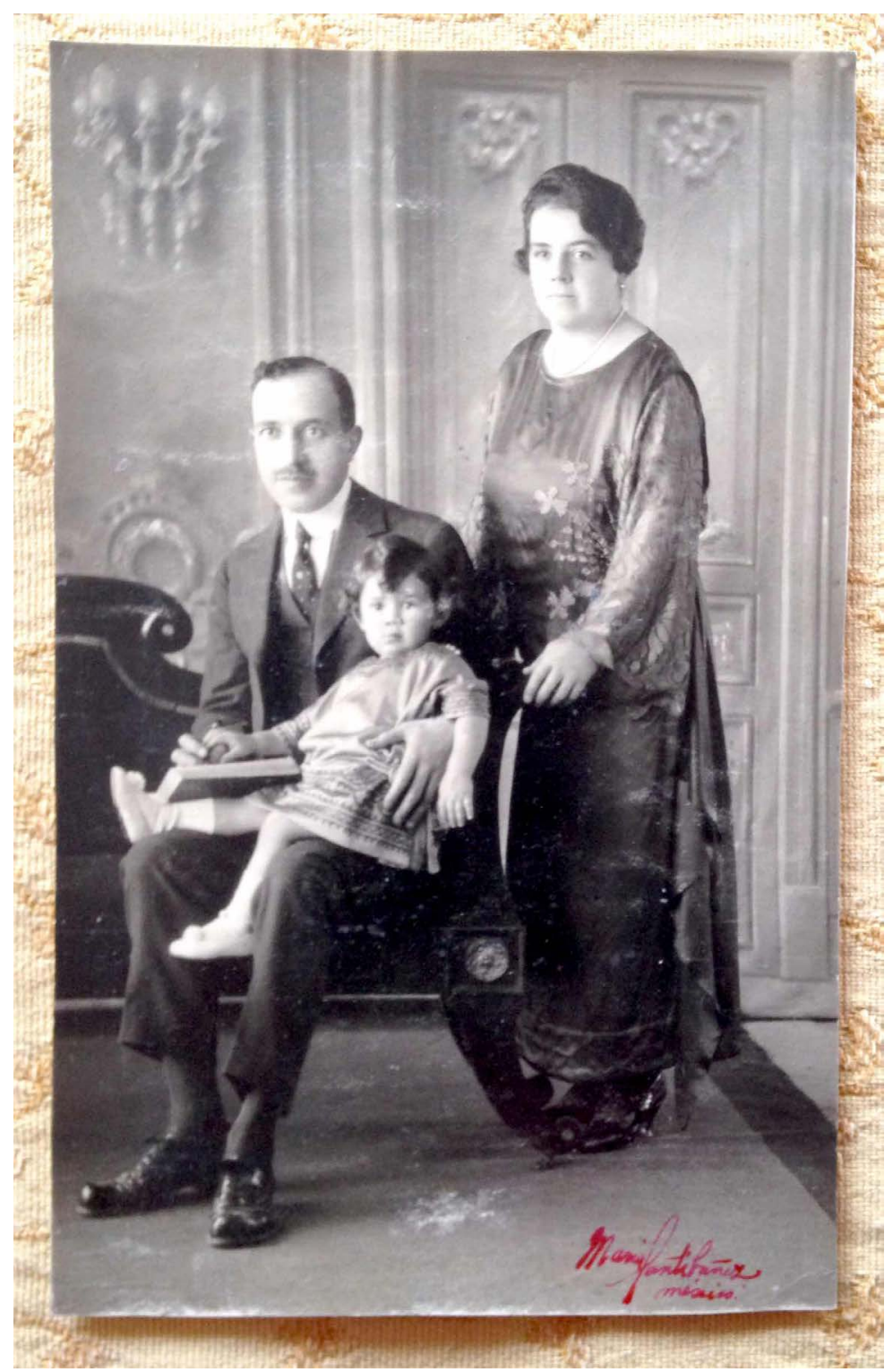

Figura 9- María Santibáñez, Familia Ruiz-Suárez, ca.I930. Col. Javier Sanchiz Ruiz 
La segunda (Figura Io), abre el abanico de formatos que se ofrecían a los clientes como en este artefacto coloreado a mano para crear la ilusión de una idílica Arcadia infantil, completo con montura en un marco floral de madera labrada y cubierto por un vidrio convexo que amplifica el efecto de irrealidad. En estas fotografías familiares, Santibáñez se entrega a la historicidad de los atuendos contemporáneos. La ilusión que sobrevive en ambos es la del tranquilo y confortable entorno hogareño burgués.

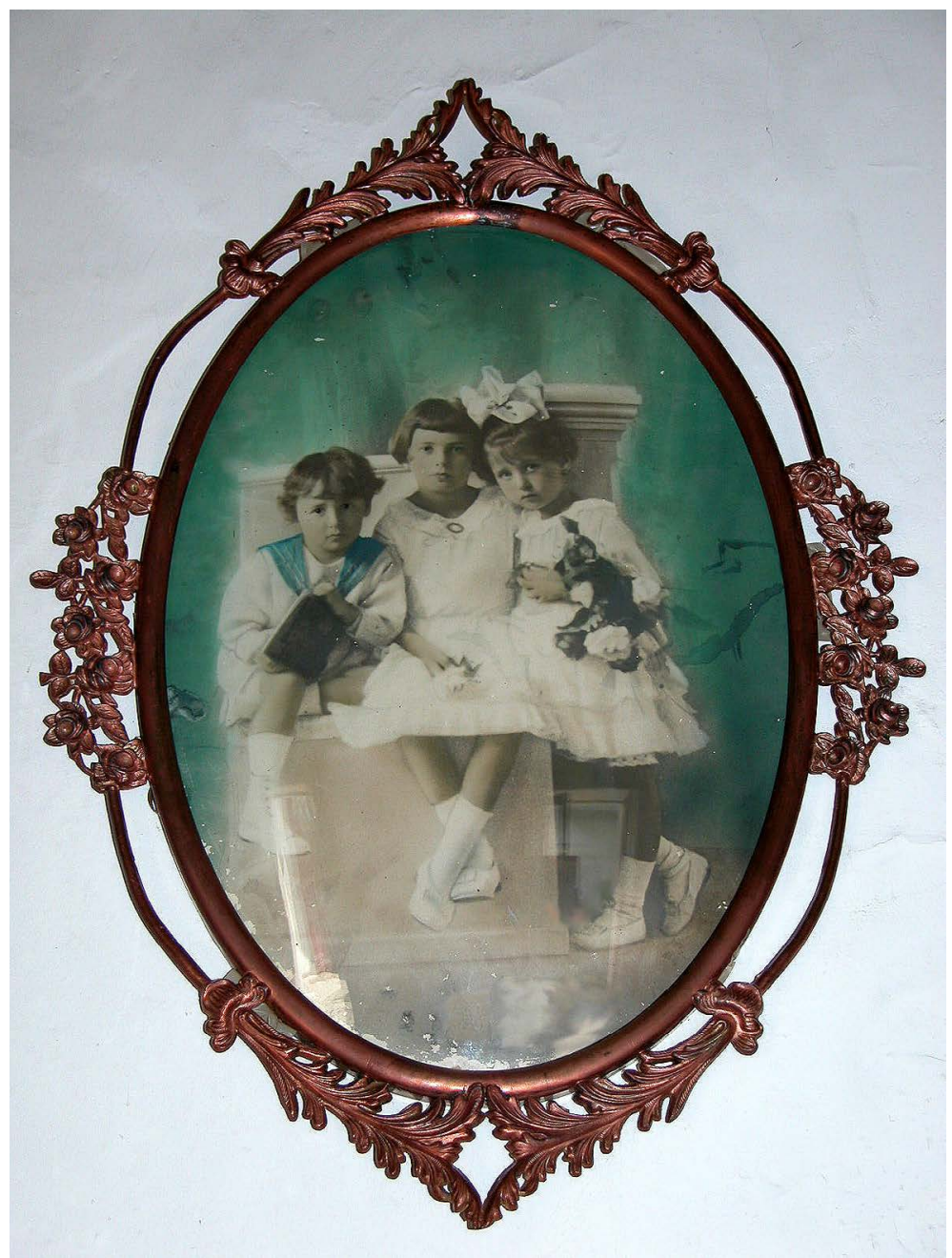

Figura ro - María Santibáñez, “Niños Arreola Baz”, c.I927. Col. Cecilia Gutiérrez Arreola (enmarcada $50 \mathrm{~cm}$ aprox.)

La pervivencia de temas grecolatinos señala sin duda un hito anómalo en la imaginería de los años veinte en México. Las mujeres de clase media, al parecer, actuaron en esta imaginería como pantallas en las que proyectaron afirmaciones sobre una emotividad e introspección femenina profunda, quizás contrapuesta a 
la frivolidad o vacuidad de la flapper - como chica moderna por excelencia - o a la "india bonita" a la que consideraron ejemplo de un provincialismo ingenuo. A pesar de la buena acogida que estos temas tuvieron en la prensa periódica del periodo, a la luz de una historiografía que privilegió la construcción del discurso nacionalista posrevolucionario, estos temas también "modernos", quedaron silenciados. Por otro lado, la ausencia de un archivo concreto sobre la producción de Santibáñez como fotógrafa de estudio - al igual que de otros fotógrafos pictorialistas - no ha ayudado a ampliar nuestra lectura de las otras modernidades que se pusieron en juego a la par del proyecto nacionalista, de ahí que resulte urgente voltear a las revistas ilustradas de I920 como "archivos específicos" en los que se despliegan modos de ver modernos no regidos por el discurso nacionalista. En cualquier caso, el retorno de los espectros clasicistas sugiere una imagen de la modernidad mexicana mucho más compleja que la bipolar que nos ha legado hasta hora la historiografía.

\section{SOBRE A AUTORA}

\section{DEBORAH DOROTINSKY ALPERSTEIN é}

pesquisadora do Instituto de Pesquisas Estéticas da Universidade Nacional Autônoma do México (UNAM). E-mail: deborahd@unam.mx

\section{REFERÊNCIAS}

AA.VV. Lecturas clásicas para niños. 2 vols. México: Secretaría de Educación Pública, I924.

ARIZA, Julia. Las otras. Presencia de lo oriental, lo afroamericano y lo indígena en la representación de mujeres en la prensa periódica ilustrada argentina de las primeras décadas del siglo XX. Revista I9e2o, Rio de Janeiro, v. X, n. I, jan./jun. 20I5. Disponible en: <http://www.dezenovevinte.net/uahI/ jariza.htm>. Consultado el 5 nov. 2016.

ÁVILA CANO, Arturo. María Santibáñez. La belleza que redimió a una fotógrafa. En: RODRIGUEZ, José Antonio; LEDESMA, Brenda; ÁVILA CANO, Arturo. Ioo años de fotografía en EL UNIVERSAL. México: Secretaría de Cultura/El Universal, Compañía Periodística Nacional, S.A. de C.V., 20I6, p.II3-I25.

BUTLER, Judith. Gender trouble: Feminism and the subversion of identity. Nueva York y Londres: Routledge, I990.

. Cuerpos que importan: sobre los límites materiales y discursivos. Buenos Aires: Paidós, 2002.

CONOR, Liz. The spectacular modern woman: feminine visibility in he I920s. Bloomington and Indianapolis: Indiana University Press, 2004.

CÓRDOVA, Carlos A. Tríptico de sombras. México: Conaculta/Cenart/Centro de la Imagen, 2012.

DALLAL, Alberto. La danza en México - tercera parte. La danza escénica popular I877-I930. México: Unam-IIE, I995. 
DIDI-HUBERMAN, George. La imagen superviviente: historia del arte y el tiempo de los fantasmas según Aby Warburg. Madrid: Abada 2009.

EDER, Rita. Modernismo, modernidad, modernización: piezas para armar una historiografía del nacionalismo cultural mexicano. En: (Coord.). El arte en México: autores, temas, problemas. México: Conaculta/Lotería Nacional para la Asistencia Pública/Fondo de Cultura Económica, 200I.

GARCÍA KRINSKY, Emma Cecilia. Mujeres detrás de la lente: Ioo años de creación fotográfica en México I9Io-20Io. México: Conaculta, 2012.

GONZÁLEZ MELLO, Renato. La máquina de pintar: Rivera, Orozco y la invención de un lenguaje. Emblemas, trofeos y cadáveres. México: Unam-Instituto de Investigaciones Estéticas, 2008.

HADATTY MORA, Yanna. Prensa y literatura para la revolución: la Novela Semanal de El Universal Ilustrado (I922-I925). México: Unam/El Universal, 2016.

HERMANSON MEISTER, Sarah. Crossing the line: Frances Benjamin Johnston and Gertrude Käsebier as professionals and artists. En: BUTLER, Cornelia; SCHWARTZ, Alexandra (Ed.). Modern women: women artists at the Museum of Modern Art. New York: The Museum of Modern Art, 2010.

HYUSSEN, Andreas. After the great divide: modernism, mass culture, postmodernism. Bloomington e Indianapolis: Indiana University Press, I986.

INDYCH, Anna. Made fot the USA: Orozco's Horrores de la Revolución. Anales del Instituto de Investigaciones Estéticas, México, v. XXIII, n. 79, 200I, p. I53-I64.http://dx.doi.org/Io.2220I/iie.I8703062e.200I.79.2087.

LOVERA, Sara. Mujeres del porvenir. Movimiento, obra y pensamiento feminista en la lucha por la democracia en México. En: MARTÍNEZ, Arturo (Coord.); ORTEGA JUÁREZ, Joel (Comp.). La izquierda mexicana del siglo XX. Libro 2. Movimientos sociales. México: Unam, 20I6, p.I45-I59.

MATUTE, Álvaro. (1993). La Revolución Mexicana: actores, escenarios y acciones. Vida cultural y política, I9I0-I929. México: Instituto Nacional de Estudios Históricos de la Revolución Mexicana, Editorial Océano, 2002.

MÉRIDA, Carlos. Retratistas mexicanos. El Universal Ilustrado, México, 2I de octubre de I920, p.I4-I5.

MONROY NASR, Rebeca. Nota en sección Testimonios del Archivo. Alquimia, México, Año 3, n. 8, enero-abril 2000, p. 39.

. Del medio tono al alto contraste: la fotografía mexicana de I920 a I940. En: GARCÍA KRINSKY, Emma Cecilia (Coord.). Imaginarios y fotografía en México I839-I970. España: Lunwerg Editores, 2005, p. II8-I39.

. Preciosismo fotográfico: María Santibáñez. Alquimia, México, año I8, n. 53, enero-abril 20I5, p. 38-48.

RÍOS CÁRDENAS, María (entrevista atribuida). La artista María Santibáñez. Mujer, periódico independiente para la elevación moral e intelectual de la mujer, México, n. 5, Io de junio de I927, p. s/n.

RODRÍGUEZ, José Antonio. Fotógrafas en México I872-I960. Madrid: Turner, 2012.

; LEDESMA, Brenda; ÁVILA CANO, Arturo. Ioo años de fotografía en El Universal. México: El Universal, Compañía Periodística Nacional, 2016.

SILVER, Kenneth E. Chaos and classicism: Art in France, Italy, and Germany, I9I8-I936. Catálogo de exhibición. Nueva York: Salomon R. Guggenheim Foundation, 2010.

SLUIS, Ageeth. Deco body, Deco city: female spectacle and modernity in Mexico City, I900-I939. Lincoln y Londres: University of Nebraska Press, 2016.

TAGG, John. The burden of representation: essays on photographies and histories. Minneapolis: University of Minnesota Press, I988.

TORREZ, David. María Santibáñez: fama, olvido, rescate y fascinación. Alquimia, México, año I4, n. 4I, enero-abril 20II, p. 6-I5. 
WARBURG, Aby. El renacimiento del paganismo: aportaciones a la historia cultural del Renacimiento europeo. Madrid: Alianza 2005.

WEINBAUM, Alys Eve et al. (Ed.) The modern girl around the world: Consumption, modernity, and globalization. Kindle edition, Duke: Duke University Press, 2008.

INDYCH, Anna. Made fot the USA: Orozco's Horrores de la Revolución. Anales del Instituto de Investigaciones Estéticas, México, v. XXIII, (79) 200I, p. I53-I64. http://dx.doi.org/Io.22201/iie.I8703062e.200I.79.2087. ZAVALA, Adriana. Becoming modern, becoming tradition: women, gender and representation in Mexican art. Pennsylvania: University of Pennsylvania Press, 2010. 